\title{
BIOLOGICAL ENHANCEMENT BASED ON CAST PROCESS AND DENITRIFICATION PERFORMANCE OF SOLID CARBON SOURCE FOR LOW C/N DOMESTIC SEWAGE
}

\author{
XIAO, J. \\ School of Civil and Architectural Engineering, Liaoning University of Technology \\ Jinzhou 121001, P. R. China \\ (e-mail:xiaojing@lnut.edu.cn) \\ (Received 24 $4^{\text {th }}$ May 2019; accepted $25^{\text {th }}$ Oct 2019)
}

\begin{abstract}
In winter, low sludge activity, low microbial abundance and low $\mathrm{C} / \mathrm{N}$ directly affect the quality of wastewater and the removal of total nitrogen in wastewater treatment plants. In this paper, the CAST process for treating low $\mathrm{C} / \mathrm{N}$ domestic sewage is selected as the experimental reactor, and the method of a combining solid carbon source with biological reinforcement is used to raise the discharge of effluent up to the standard. The target bacteria were immobilized with artificial filler, and different bacterial components were placed in different positions of CAST reactor. The ammonia nitrogen, total nitrogen and COD in the effluent of the system were measured, and the changes of microbial community structure in the treatment process were analyzed by PCR-DGGE technology, so as to determine the effect of solid carbon source and biological reinforcement on the denitrification performance of CAST process.
\end{abstract}

Keywords: domestic sewage, activated sludge, high efficiency denitrification, aerobic denitrifying bacteria, community structure

\section{Introduction}

Nitrogen discharged into it will have a great impact on the water body. Therefore, denitrification is an important part of sewage treatment. At present, sewage treatment plants around the world need to be upgraded, and efficient denitrification is a key issue in sewage treatment (Adouani et al., 2015). For domestic sewage, the main influent nitrogen is ammonia nitrogen. At present, the denitrification process in activated sludge system is mainly composed of nitrification process and denitrification process. Any link of the process is limited, which will affect the final denitrification effect of the system and directly affect the quality of the effluent (Magrí et al., 2012). For the traditional denitrification principle of activated sludge system, the main factors that restrict the nitrification process include insufficient aeration and low abundance of nitrifying bacteria; the main factors that restrict the denitrification process include excessive aeration leading to the restriction of denitrifying bacteria and insufficient carbon source restricting the denitrification process (Bellucci et al., 2013).

In this paper, Cyclic Activated Sludge Technology (CAST) process for treating low $\mathrm{C} / \mathrm{N}$ domestic sewage was selected as the experimental reactor. Biological enhancement and solid carbon source were used to enhance the denitrification performance of the reactor. Nitrification and denitrification can improve the denitrification performance simultaneously. Nitrifying bacteria, anoxic denitrifying bacteria, aerobic denitrifying bacteria and corn cob solid carbon source were used to enhance the denitrification performance of CAST process for treating low C/N domestic sewage (Chen et al., 2016). The changes of COD, $\mathrm{NH}_{4}{ }^{+}-\mathrm{N}$ and $\mathrm{TN}$ in the control group and the experimental group with biological agents and corncob were investigated during the experiment. The changes of activated sludge community structure in the two reactors were analyzed by 
PCR-DGGE technology, and the adaptability and stability of artificial enhanced biological agents in the system were determined.

\section{Materials and Methods}

\section{Experimental materials}

\section{Strains and activated sludge}

Nitrobacteria were gathered from the compound nitrifying agent $\mathrm{M}$ preserved in the laboratory. Anoxic denitrifying bacteria come from the compound anoxic denitrifying bacteria agent $\mathrm{Q}$ preserved in the laboratory. Aerobic denitrifying bacteria were compounded by P.sp., P.stutzeri, P.aeruginosa according to $1: 1: 1$. Activated sludge is taken from the surplus sludge of Sewage Treatment Plant close to river in a county.

\section{Corncob}

Corn cob for experiment comes from Shapingba District of Chongqing City and is cut after recycling, screened by 1 mesh screen, and then screened by 2 meshes screen. Corncobs on the screen were used as experimental materials. Corncobs were about $1-2 \mathrm{~cm}$ in diameter. Two days after drying in an oven at $30^{\circ} \mathrm{C}$, it was stored in a dryer.

\section{Inlet}

The background monitoring of the influent quality of domestic sewage treatment plant close to river in a county was carried out. The actual influent COD was $100-150 \mathrm{mg} / \mathrm{L}$, TN was $20-40 \mathrm{mg} / \mathrm{L}$, and $\mathrm{NH}_{4}{ }^{+}-\mathrm{N}$ was $15-30 \mathrm{mg} / \mathrm{L}$. In order to better simulate the water quality of the sewage treatment plant, the water used in this experiment was diluted and $\left(\mathrm{NH}_{4}\right)_{2} \mathrm{SO}_{4}$ and $\mathrm{NaNO}_{3}$ were prepared for school domestic sewage. The control of COD was about $150 \mathrm{mg} / \mathrm{L}$, TN was about $40 \mathrm{mg} / \mathrm{L}$, and $\mathrm{NH}_{4}{ }^{+}-\mathrm{N}$ was about $30 \mathrm{mg} / \mathrm{L}$. It is generally considered that the wastewater with COD less than $200 \mathrm{mg} / \mathrm{L}$ and wastewater COD/TN is 5.6.

Table 1. Model of experimental instrument

\begin{tabular}{c|c|c}
\hline Instrument & Manufacturer & Model \\
\hline Bed temperature incubator & $\begin{array}{c}\text { Shanghai Fuma Experimental } \\
\text { Equipment Co., Ltd. }\end{array}$ & QYC200 \\
\hline $\begin{array}{c}\text { Digital display electrothermal } \\
\text { incubator }\end{array}$ & $\begin{array}{c}\text { Shanghai Boxun Industrial Co., Ltd. } \\
\text { Medical Equipment Factory }\end{array}$ & HPX-9297MBE \\
\hline Super Clean Workbench & $\begin{array}{c}\text { Shanghai Boxun Industrial Co., Ltd. } \\
\text { Medical Equipment Factory }\end{array}$ & SW-CJ-ICU \\
\hline One-thousandth balance & Metler Toledo & AL104-IC \\
\hline optical microscope & Motic & BA200 \\
\hline
\end{tabular}

\section{Design and operation of CAST reactor}

Two groups of parallel reactors were set up, the control group and the experimental group respectively, the reactor schematic diagram is shown in Figure 1. Volumes of anaerobic selective zone, pre-reaction zone and main reaction zone in CAST reactor are $10.5 \mathrm{~L}, 12 \mathrm{~L}$ and $126 \mathrm{~L}$, respectively. The anaerobic selective zone $\mathrm{L} \times \mathrm{B} \times \mathrm{H}=$ $(300 \times 100 \times 350) \mathrm{mm}$; the pre-reaction zone is L-type, $300 \mathrm{~mm}$ long, $100 \mathrm{~mm}$ wide on the top and $200 \mathrm{~mm}$ wide on the bottom, $350 \mathrm{~mm}$ high on the front and $600 \mathrm{~mm}$ high on 
the back; the main reaction zone $\mathrm{L} \times \mathrm{B} \times \mathrm{H}=(700 \times 300 \times 600) \mathrm{mm}$. The operation period is set up to be 4 hours, water intake 1 hour, aeration 2 hours, standing 1 hour, drainage 1 hour, and aeration begins during water intake. MLSS is set at $3500 \mathrm{mg} / \mathrm{L}$, water filling ratio is $1 / 3$, reflux ratio of mixed liquid is $30 \%$, bottom microporous explosion is used, DO is controlled at aeration stage to be $4.0-5.0 \mathrm{mg} / \mathrm{L}$. During the experiment, no sludge was discharged and reactor operated at room temperature, and the temperature was about $20^{\circ} \mathrm{C}$.

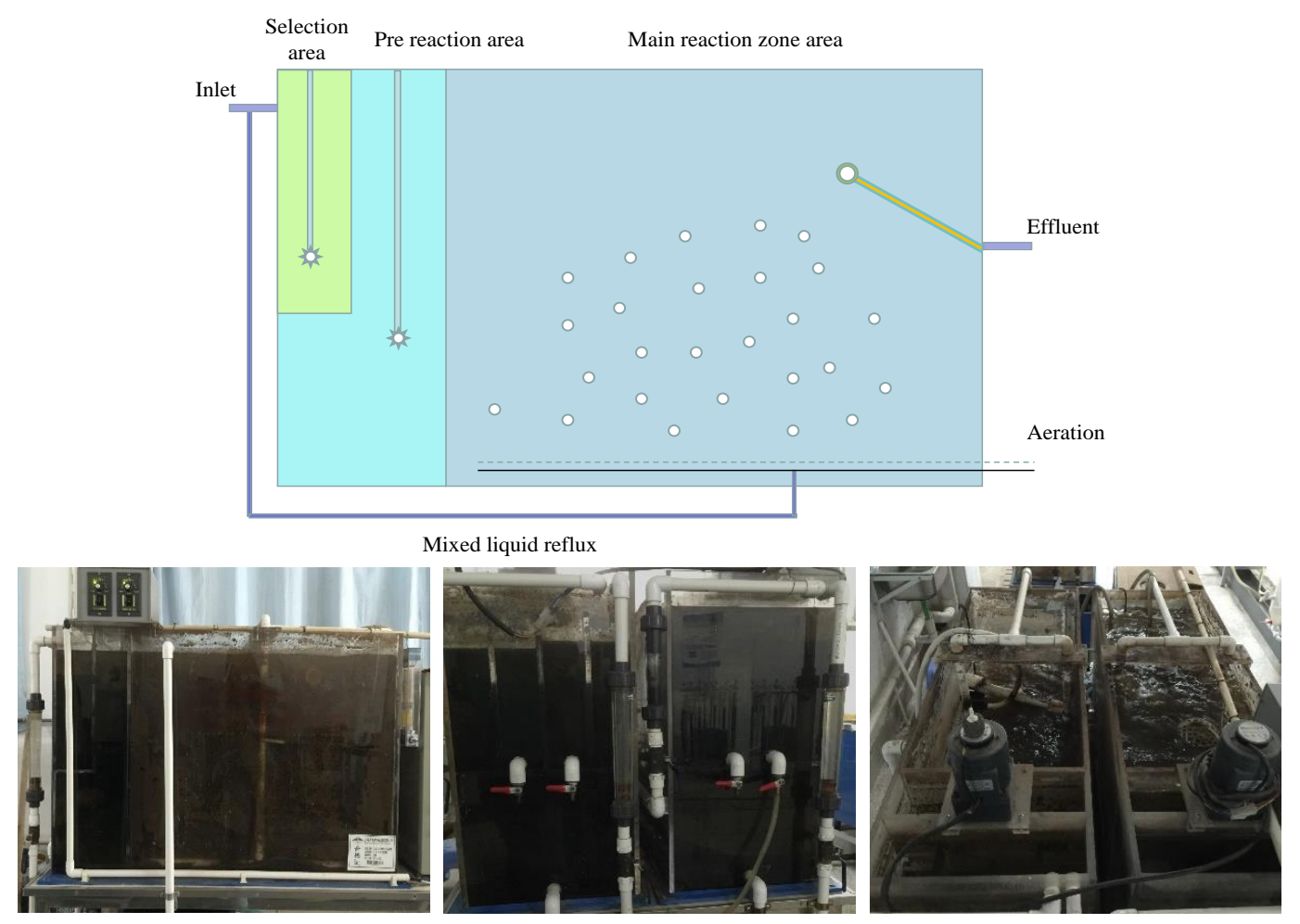

Figure 1. Diagram and physical diagram of CAST reactor

\section{PCR-DGGE method of sewage sludge}

\section{Principle of PCR-DGGE}

By using polyacrylamide gel with chemical denaturant gradient, DGGE can dissolve PCR products differently. The same length of different DNA was amplified in the process of PCR, so all DNA fragments in the product of PCR had the same length, but the nucleotide sequence was different. Through the DGGE experiment, different DNA fragments will stop migration at different positions of the gel due to the different chain breaking behavior along the chemical gradient. Therefore, PCR-DGGE technology can distinguish sequence differences with the same size fragments.

\section{DNA extraction and PCR amplification from sludge}

DNA extraction method was carried out according to the instructions of OMEGA soil DNA extraction kit. The $16 \mathrm{SrDNA}$ V3 region was selected as the amplification region, and the common primers $338 \mathrm{~F}-\mathrm{GC}$ and $518 \mathrm{R}$ were used as the primers. Marker 
uses DL2000 and the corresponding fragment size from top to bottom is 2000, 1000, 750, 500, 250, 100.

Primer sequence is:

338-GC: 5 -CGCCCGCCGCGCGCGGCGGGCGGGGCGGGG

GCACGGGGGGACTCCT ACGGGAGGCAGCAG -3

518R: 5 - ATTACCGCG GCT GCTGG-3

PCR reaction system was as follows: Total reaction volume was $50 \mu \mathrm{L}$, including $10 \times$ Taq buffer $5 \mu \mathrm{L}$, dNTPmix $4 \mu \mathrm{L}$, upstream and downstream primers $(10 \mu \mathrm{M}) 2 \mu \mathrm{L}$, DNA template $4 \mu \mathrm{L}$, Taq enzyme $0.5 \mu \mathrm{L}$, sterilized ultra-pure water $32.5 \mu \mathrm{L}$. Reaction conditions were as follows: pre-reaction at $95^{\circ} \mathrm{C}$ for 5 minutes; denaturation at $95^{\circ} \mathrm{C}$ for 1 minute; annealing at $58^{\circ} \mathrm{C}$ for $45 \mathrm{~s}$; elongation at $72^{\circ} \mathrm{C}$ for 1 minute; reaction cycle 35 times and elongation at $72^{\circ} \mathrm{C}$ for 5 minutes.

\section{$D G G E$ experimental steps}

Preparation of gel for DGGE: Firstly, after $24 \mathrm{~g}$ urea was completely dissolved in water bath at $50^{\circ} \mathrm{C}, 10 \mathrm{ml}$ deionized formamide, $3.896 \mathrm{~g}$ acrylamide, $0.1038 \mathrm{~g}$ methylene bisacrylamide, $1 \mathrm{ml} 50 \times \mathrm{TAE}$ and $50 \mu \mathrm{L}$ glycerol were added to the volume of $50 \mathrm{~mL}$. Finally, $80 \mu \mathrm{L} 10 \%$ persulfate amine and $110 \mu \mathrm{L}$ TEMED were added rapidly. After mixing, gel was poured immediately and placed for more than 3 hours to be gelled.

Silver staining: 1) Fixation: fixed with 10\% glacial acetic acid of $300 \mathrm{~mL}$ for 30 minutes; 2) Cleaning: rinsed with deionized water for 3 times, 2 minutes each time; 3) Silver staining: added $37 \%$ formaldehyde $400 \mathrm{~mL}$ in $0.1 \% \mathrm{AgNO}_{3}$ solution, dyed with this silver staining solution for 25 minutes; 4) Washing: washed with pre-cooled deionized water for three times, the time was $30 \mathrm{~S}, 15 \mathrm{~S}, 30 \mathrm{~S}$, respectively. 5) Development: weigh $15 \mathrm{~g} \mathrm{NaOH}, 0.19 \mathrm{~g}$ sodium tetraborate, dissolve in sterile deionized water, constant volume to $1000 \mathrm{~mL}$, add $1.5 \mathrm{~mL} 37 \%$ formaldehyde (before use). The developer was used to develop for 12-15 minutes. The development time should not be too long, when the development is less than what you need, it will be terminated in advance, and color rendering time can be prolonged in winter. 6) Termination: When the strip appears, terminate for 3 minutes with fixative. Wash twice, 2 minutes each time (note: if the termination time is too long, the strip will fade). After developing, the UVP gel imaging system was photographed and stored under white light and analyzed by Quantity One-4.6.2 software.

\section{Result and Discussion}

\section{Design of experimental group}

CAST process for treating low $\mathrm{C} / \mathrm{N}$ domestic sewage was selected as the experimental reactor in this paper. CAST process is completely mixed in space, anaerobic, anoxic and aerobic in time (Dvorák et al., 2013). If the aeration process and static precipitation process are not properly controlled, it will easily lead to the short anoxic section in the system due to excessive aeration, which directly affects the denitrification process. The main removal site of organic matter is the main reaction area, heterotrophic bacteria carry out nutrient metabolism under aerobic condition to achieve carbon removal; the main reaction area is also the main place for nitrogen removal. By controlling DO in the reactor, nitrification and denitrification can be realized in the same reactor, and then nitrogen removal can be realized. 
Phosphorus-accumulating bacteria can absorb excessive phosphorus by PHB in the main reaction zone under aerobic conditions, forming phosphorus-rich sludge, and then complete phosphorus removal through sludge discharge (Duan et al., 2012). In addition, sludge-water separation is realized at the end of one cycle in the main reactor. During the settling stage, the reactor does not receive water, which ensures a good static settling effect. In this stage, denitrifying bacteria can denitrify by using carbon sources in sludge.

CAST process usually has better carbon removal effect, but nitrogen and phosphorus removal is limited (Fang et al., 2015). (1) Nitrification is incomplete. Nitrification is mainly realized in the main reaction zone of CAST process. In the aeration stage, $\mathrm{NH}_{4}{ }^{+}-\mathrm{N}$ is oxidized to $\mathrm{NO}_{3}{ }^{-}-\mathrm{N}$ and $\mathrm{NO}_{2}{ }^{-}-\mathrm{N}$ by nitrifying bacteria and nitrosobacteria. In this process, nitrifying bacteria compete with heterotrophic bacteria DO, which makes nitrification need longer aeration time, which directly leads to lower water filling in CAST process, the ratio of influent volume to total volume is difficult to improve in each cycle, and the volume utilization rate is low. (2) Denitrification is not complete. CAST process consists of two parts of denitrification, $20 \%$ of which is refluxed to realize denitrification using front-end carbon sources; $80 \%$ of denitrification is achieved in the main reaction zone, mainly in the period of static precipitation and drainage, but after sludge precipitation, sludge and water are insufficiently mixed, nitrate can not effectively contact with activated sludge, which limits denitrification. The main reaction zone of CAST process can achieve anaerobic, deficient and good plugging flow in time, and realize simultaneous nitrification and denitrification. However, the changing environment also leads to the failure of dominant bacteria to play their role to the greatest extent at all stages. At the same time, the abundance of dominant microorganisms will also be affected by environmental changes, resulting in a decline in abundance.

Denitrification performance of CAST process for treating low $\mathrm{C} / \mathrm{N}$ domestic sewage is affected by many factors. Considering from the point of view of microorganisms and carbon sources, it mainly includes low types and abundance of denitrifying microorganisms and insufficient organic matter content in low $\mathrm{C} / \mathrm{N}$ water body. In view of the above problems, biological enhancement and solid carbon source were used to enhance the denitrification performance of the reactor (Huang et al., 2013).

(1) Selection of biofortifier and solid carbon source. The selection of biofortifier mainly starts with the species and abundance of denitrifying bacteria. As far as the CAST process is concerned, it mainly includes nitrifying bacteria to strengthen the nitrification process and denitrifying bacteria to strengthen the denitrification process. In order to remedy the shortage of denitrification caused by the short anoxic section in the same reactor, anoxic denitrifying bacteria and aerobic denitrifying bacteria were selected as denitrifying bacteria. Corn cob was selected as the additional carbon source of CAST process. By adding corn cob, the system $\mathrm{C} / \mathrm{N}$ was improved, which provided conditions for efficient denitrification of the system.

(2) Dosage mode of biofortifier. In order to immobilize microorganisms to the greatest extent, the method of combining polyethylene biological filler with biofortifier with rough surface and loose fibers was adopted. The fillers with diameter of $80 \mathrm{~mm}$ were selected, and the biofortifier was first expanded, then the fillers were connected in series and immersed in the bacterial solution for film hanging. Five days later, the filler was added to the reactor. 
(3) The way of adding solid carbon source of corn cob. In order to ensure that the solid carbon source of corn cob does not cause secondary pollution to the reactor, polyethylene biological filler was used to wrap and fix the reactor. The combination of corn cob and filler not only can provide carbon source for the system, but also can be used as biological carrier to increase the microbial abundance of the system. In order to improve the space utilization rate of solid carbon source of corncob and avoid unnecessary waste of carbon source of corncob, the biofortifier was fixed on the solid carbon source of Corncob by spraying microbial agent, and then added to the reactor. Carbon release experiments show that $80 \%$ of the carbon source will be released in the first two days of corn cob immersion. When the system needs additional carbon source for a long time, in order to avoid secondary pollution caused by high COD in the initial stage of solid carbon source immersion, the corn cob should be immersed for two days before drying and then using. When the system needs to add carbon source for short-term emergency treatment, corn cob soaking solution can be used instead of methanol which is currently used more (Huang et al., 2013; Islas-García et al., 2015).

(4) Reactor was operated initially. In order to investigate the carbon and nitrogen removal performance of the system and determine the solid carbon source dosage of corn cob in the experimental group, $\mathrm{COD}, \mathrm{NH}_{4}{ }^{+}-\mathrm{N}$ and $\mathrm{TN}$ were measured in a stable CAST reactor for 5 consecutive days.

(5) Solid carbon source of corn cob and the dosage of biofortifier in the experimental group were preliminarily determined. The results of background monitoring for 5 days showed that the quality of artificial controlled influent water was basically stable, COD was about $150 \mathrm{mg} / \mathrm{L}$, TN was about $35 \mathrm{mg} / \mathrm{L}$ and $\mathrm{NH}_{4}{ }^{+}-\mathrm{N}$ was about $25 \mathrm{mg} / \mathrm{L}$. The effluent COD is about $50 \mathrm{mg} / \mathrm{L}, \mathrm{NH}_{4}{ }^{+}-\mathrm{N}$ is about $10 \mathrm{mg} / \mathrm{L}$, the removal rate is about $60 \%, \mathrm{TN}$ is about $25 \mathrm{mg} / \mathrm{L}$, the removal rate is about $30 \%$. The denitrification performance of corn cob combined with biofortifier in activated sludge system showed that when corn cob existed in activated sludge system for 20 days, the removal rate of $\mathrm{NO}_{3}{ }^{-} \mathrm{N}$ of $30 \mathrm{mg} / \mathrm{L}$ was maintained at $35 \%-40 \%$. In order to achieve the initial TN standard of CAST process, the rough calculation group needs to add $500 \mathrm{~g}$ solid carbon source of corncob. Corn cob solid carbon source is hung in series at the back end of CAST main reaction zone. The number of nitrifying bacteria film-forming fillers is 16 in a series, which are vertically attached to the front end of the main reaction zone of CAST in series, and 12 in a series of denitrifying bacteria film-forming fillers, which are vertically attached to the front and back end of the main reaction zone of CAST respectively. In order to enhance the mixing degree of microorganisms and water and avoid sludge loss, all packings in series are fixed at the bottom, and the top packings are guaranteed below the water surface at the end of the reactor drainage (Krustok et al., 2015).

\section{Packing observation of CAST reactor experimental group}

Solid carbon source of filler and corncob after 20 days operation of CAST reactor is observed in Fig. 2. Microscopic observation showed that there were a large number of microorganisms on the surface of film-forming filler and corncob., which could be fixed by bio-strengthening bacteria agent to reduce bacterial loss, increase the microbial abundance on the filler, and then increase the contact area of sludge during the static settling period, which was conducive to the improvement of the nitrogen removal performance of the reactor (Joo et al., 2005). 


\section{Effect of bioaugmentation and solid carbon source on denitrification performance of CAST process}

In order to investigate the ability of corn cob and biofortifier to improve the denitrification performance in low $\mathrm{C} / \mathrm{N}$ domestic sewage treatment, a pilot study was carried out by using CAST process to treat low $\mathrm{C} / \mathrm{N}$ domestic sewage (Jianhua et al., 2016). The experimental results are shown in Figure 3.
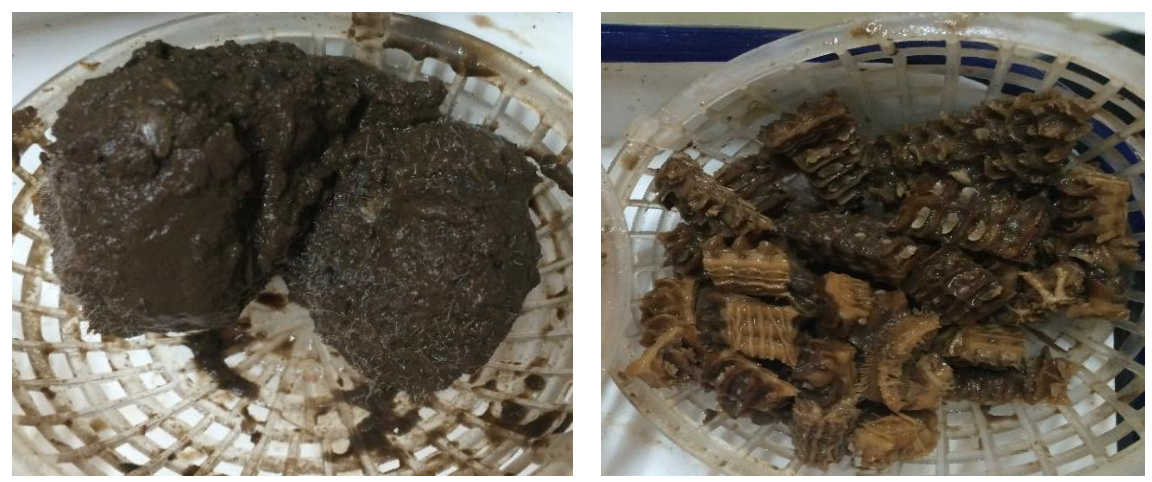

Figure 2. Physical drawings of stuffing and corncob after film hanging
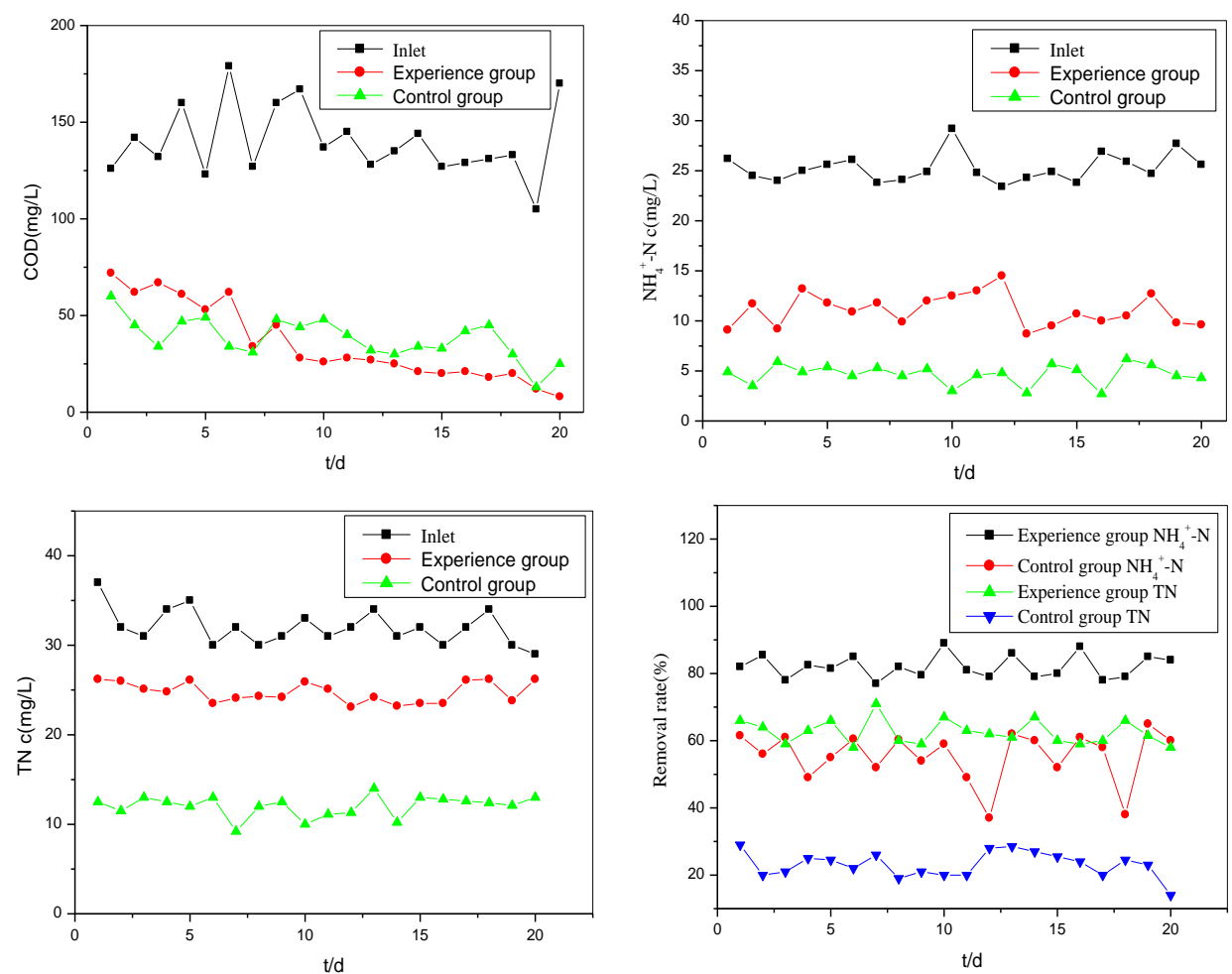

Figure 3. Changes of water quality index of reactor before and after intensification treatment

The change of COD in the effluent of the experimental group and the control group showed that the effluent COD of the control group was basically stable and the average COD in the effluent was $41.8 \mathrm{mg} / \mathrm{L}$, reaching the first grade A standard $(50 \mathrm{mg} / \mathrm{L})$. The effluent COD of the experimental group did not increase significantly. Before 9 days, 
the effluent COD was similar to that of the control group and maintained at about $45 \mathrm{mg} / \mathrm{L}$ (Lu et al., 2014). After that, COD decreased slightly, and the average COD of effluent was $30.1 \mathrm{mg} / \mathrm{L}$, and remained below $50 \mathrm{mg} / \mathrm{L}$ all the time. It is speculated that the nitrogen removal performance of the system and the utilization rate of microbial carbon source may be improved by adding biofortifier, which may lead to the decrease of COD in the effluent of the experimental group. The results showed that the COD of effluent from the experimental tissues did not increase significantly. When corn cob was used as carbon source of external reinforcement in activated sludge system, it would not cause secondary pollution to the raw water. The change of $\mathrm{NH}_{4}{ }^{+}-\mathrm{N}$ concentration in the effluent of the experimental group and the control group showed that the removal rate of $\mathrm{NH}_{4}{ }^{+}-\mathrm{N}$ in the control group was limited. The average removal rate of $\mathrm{NH}_{4}{ }^{+}-\mathrm{N}$ in the effluent was $11.35 \mathrm{mg} / \mathrm{L}$, which was about $55 \%$. The effluent $\mathrm{NH}_{4}{ }^{+}-\mathrm{N}$ concentration in the experimental group was significantly lower than that in the control group, with an average $\mathrm{NH}_{4}{ }^{+}-\mathrm{N}$ concentration of $4.58 \mathrm{mg} / \mathrm{L}$. The addition of nitrifying bacteria increases the abundance of nitrifying bacteria in the system (Liu et al., 2015). When the aeration condition is the same, increasing the abundance of nitrifying bacteria can enhance the nitrification and reduce the concentration of $\mathrm{NH}_{4}{ }^{+}-\mathrm{N}$ in the system.

The change of TN concentration in the effluent of the experimental group and the control group showed that the removal rate of TN in the control group was low, and the average TN concentration in the effluent was $25.03 \mathrm{mg} / \mathrm{L}$. The TN concentration in effluent of the experimental group was significantly lower than that of the control group, with an average concentration of $12.11 \mathrm{mg} / \mathrm{L}$, reaching the first a standard $(15 \mathrm{mg} / \mathrm{L})$. Bioaugmentation has an obvious effect on the removal rate of TN in the system (Quan et al., 2011). It is speculated that bioaugmentation improves the denitrification performance of the system. Anoxic denitrifying bacteria increase the abundance of conventional denitrifying bacteria in the system, and then improve the denitrification performance of the system under anoxic conditions (Szogi et al., 2015). Anaerobic, anoxic and aerobic alternation occurs in the same vessel in CAST process, which makes it difficult to strictly control dissolved oxygen. After the main reaction zone stops aeration, there is no anoxic stirring in the system, resulting in short anoxic period in the main reaction zone of CAST and insufficient slurry mixing in the anoxic period, which directly restricts denitrification and denitrification of the system (Shoda and Ishikawa, 2014). Adding aerobic denitrifying bacteria can realize the nitrification and denitrification process at the same time under the aeration condition in the main reaction zone of CAST, and improve the denitrification performance of the system (Urakawa et al., 2006).

The removal rates of $\mathrm{NH}_{4}{ }^{+}-\mathrm{N}$ and $\mathrm{TN}$ in the experimental group and the control group showed that the experimental group had obvious effect on the denitrification of the system. Denitrification performance of CAST process for treating low $\mathrm{C} / \mathrm{N}$ domestic sewage can be improved by the combination of bio-intensifying bacteria and solid carbon source of corncob.

\section{Electron microscopic analysis of CAST reactor sludge}

The initial sludge of the experimental group and the control group and the sludge after 20 days of operation were observed by scanning electron microscopy. The results are shown in Fig. 4. A and B represent the sludge at the initial stage of the experiment and the sludge after 20 days of reactor operation. The results showed that at the beginning of the experiment, the sludge structure of the experimental group and the 
control group was basically the same, crisp and porous, and filamentous bacteria and bacilli could be clearly seen (Skouteris et al., 2012; Pan et al., 2015). After 20 days of operation of the reactor, the sludge structure of the experimental group basically did not change much, a large number of rod-shaped bacteria could be clearly seen, and the sludge performance was good. The structure of the control group was slightly loose. It was speculated that the starvation of some microorganisms in the activated sludge might be due to insufficient carbon sources in the water, and the sludge structure began to loosen.

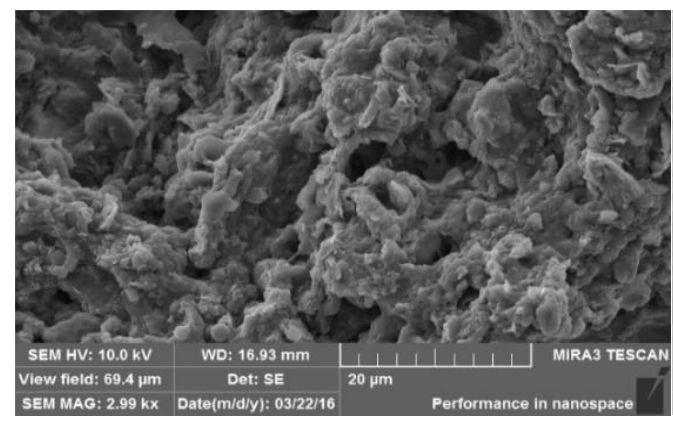

A

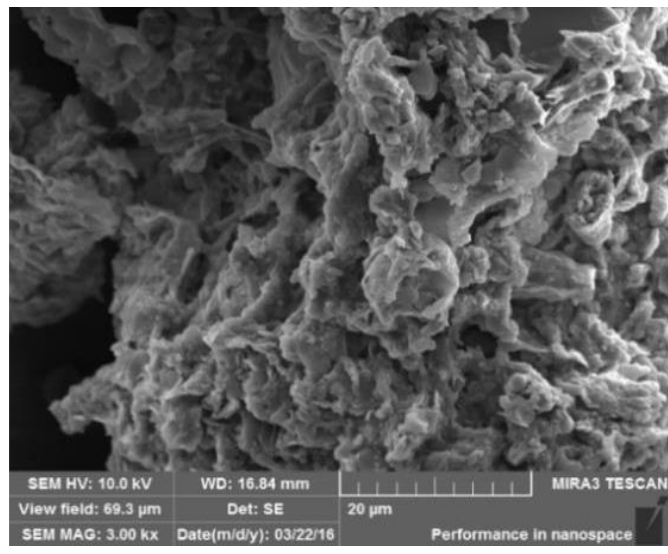

$\mathrm{C}$

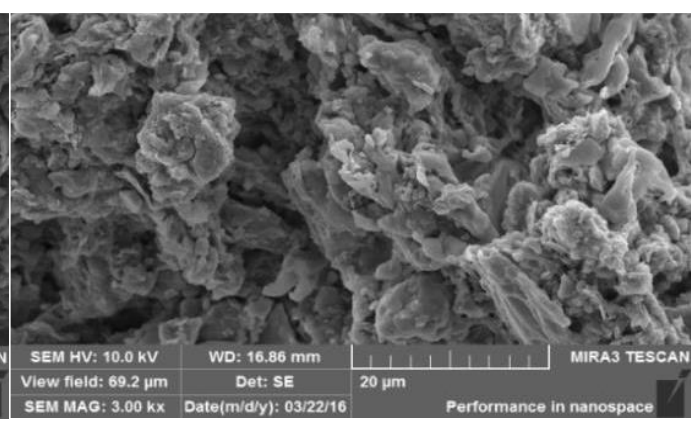

B

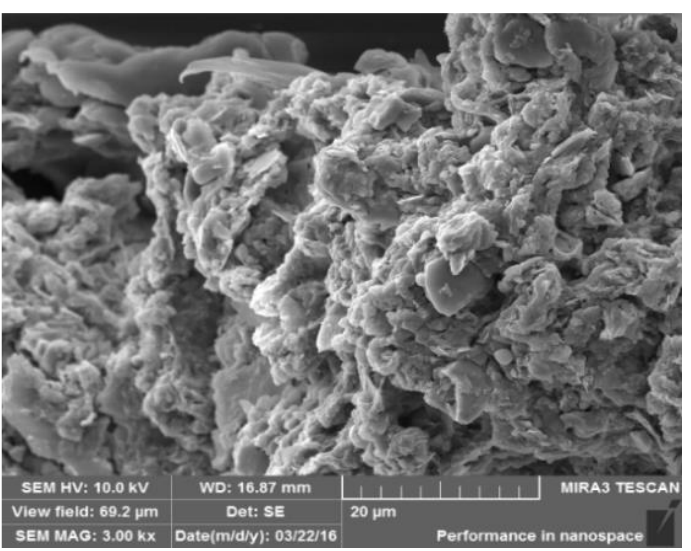

$\mathrm{D}$

Figure 4. A-D: Electron Microscopic Scanning of Sludge from Two Reactors at Different Stages

\section{Analysis of sludge community structure in CAST reactor}

Results of sludge PCR in DNA16SrDNAV3 region

The results of $16 \mathrm{SrDNAV} 3$ region PCR amplification of total DNA of the samples are shown in Fig. 5. From the figure, we can see that all the DNA of the five samples was amplified. The size of the fragments is about $250 \mathrm{bp}$. The band brightness is suitable and there is no non-specific amplification, which meets the requirements of the follow-up DGGE experiments.

\section{Analysis of sludge community structure}

The sludge DGGE and swimming lane recognition maps of the experimental group and the control group after 20 days of operation are shown in Fig. 6, respectively. A is the band corresponding to the added anoxic denitrifying agent, $\mathrm{B}$ is the band 
corresponding to the added nitrifying agent, $\mathrm{C}$ is the band corresponding to the added aerobic denitrifying agent, $\mathrm{D}$ is the band of sludge after 20 day operation of the experimental group reactor and $\mathrm{E}$ is the band of sludge after 20 days operation of the control group reactor.

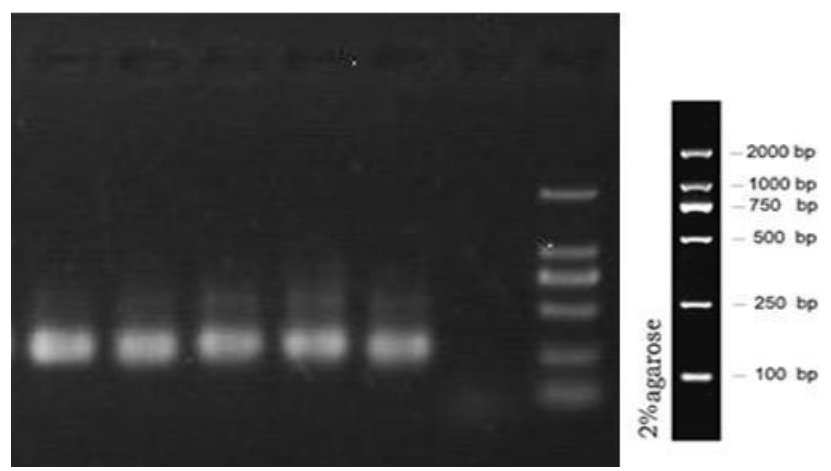

Figure 5. Gel electrophoresis of PCR product in total DNA16SrDNAV3 region of sample

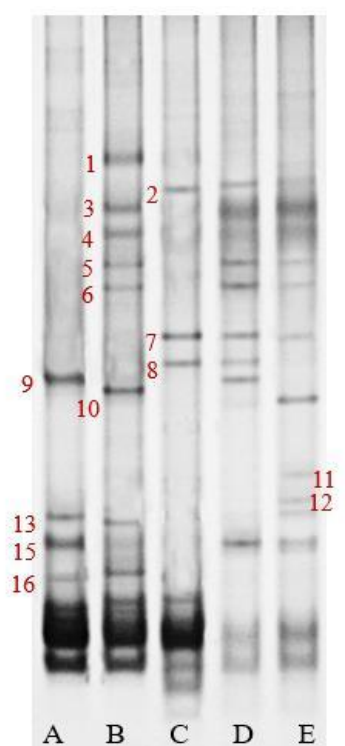

Figure 6. Sludge DGGE Map. A: anoxic denitrifying bacteria agent; B: nitrifying bacteria agent; $C$ : good nutrient denitrifying bacteria agent; D: Sludge in the experimental group after 20 days; E: Sludge in control group after 20 days

DGGE map showed that the bands below No. 17 were not separated and no analysis was done. As far as the obvious characteristic bands are concerned, the added anoxic denitrifying bacteria agent includes three characteristic bands, 9, 13 and 15 respectively; the added nitrifying bacteria include six characteristic bands, 1, 3, 4, 5, 6 and 10 respectively; and the added aerobic denitrifying bacteria include three characteristic bands, 2, 7 and 8, respectively. In the control group, 2, 3, 4, 5, 6, 7, 10, 13 and 15 bacterial agents were detected, which indicated that the above eight bacterial species existed in the original activated sludge system and were not exotic and had good adaptability. The dominant denitrifying bacteria in the control group were $3,4,10,2,7$, 
13 and 15, and the characteristic strips in the experimental group were 2, 3, 4, 5, 6, 7, 8, 9 and 15. Analysis of the sludge bands of the experimental group and the control group after 20 days of operation showed that compared with the control group, the abundances of the experimental group 2, 3, 5, 6, 7 and 15 increased, the abundances of 4 decreased, and the abundances of 10 and 13 completely disappeared. The change of dominant nitrifying bacteria in the control group showed that the addition of biofortifier gradually replaced the dominant nitrifying bacteria corresponding to 4 in the original activated sludge system, completely replaced the corresponding nitrifying bacteria of 10 , and increased the abundance of nitrifying bacteria corresponding to 3,5 and 6 , and gradually became the dominant nitrifying bacteria in the system. The change of dominant denitrifying bacteria in the control group showed that the dominant denitrifying bacteria corresponding to 13 in the original activated sludge system were completely replaced and the corresponding denitrifying bacteria of 2, 7, 13 and 15 were strengthened by adding biofortifier. In addition to the above characteristic bands, 11 and 12 bands of sludge in the control group disappeared. It was speculated that the corresponding strains of 11 and 12 bands were heterotrophic bacteria. While the species and abundance of denitrifying bacteria increased, the species of heterotrophic bacteria decreased. In addition to the above characteristic bands, 8 and 9 in the sludge Atlas of the experimental group are new bands, representing an aerobic denitrifying bacteria and anoxic denitrifying bacteria, which belong to exotic microorganisms. The appearance of 8 and 9 bands indicates that 8 and 9 corresponding strains can exist stably in the sludge system, and 9 bands corresponding denitrifying bacteria gradually become the dominant denitrifying bacteria of the experimental group.

In summary, 2, 3, 4, 5, 6, 7, 10, 13 and 15 of the added biofortifiers exist in the original sludge system, indicating that the above eight bacteria are not alien species and have high stability. The enrichment of 4 decreased and 10 and 13 completely disappeared, indicating that the corresponding strains of 4 were gradually replaced, and the corresponding strains of 10 and 13 were completely replaced within 20 days. The abundance of 2, 3, 5, 6, 7 and 15 strains increased, which indicated that the six strains could grow steadily in the system. The corresponding strains of 1 in the added biofortifier were not detected in the sludge of the experimental group, which indicated that the two strains could not exist stably in the system. The corresponding strains of 8 and 9 could exist stably in the sludge of the experimental group, and the denitrifying bacteria corresponding to 9 bands gradually became the dominant denitrifying bacteria in the experimental group.

Among the six kinds of nitrifying bacteria added, there are three kinds which can exist stably in the system; among the three kinds of anoxic denitrifying bacteria added, there are two kinds which can exist stably in the system length; and among the three kinds of aerobic denitrifying bacteria added, there are three kinds which can exist stably in the system length. The results showed that the structure of denitrification bacteria and the denitrification performance of the sludge system could be effectively improved by adding biofortifier.

\section{Conclusion}

In view of the low denitrification performance of CAST process in treating low $\mathrm{C} / \mathrm{N}$ domestic sewage, biological strengthening and solid carbon source were used to enhance the denitrification performance of CAST process. By increasing the abundance 
of nitrifying bacteria and anoxic denitrifying bacteria, the abundance and species of denitrifying microorganisms in the system can be improved; by adding aerobic denitrifying bacteria, the problem of inadequate denitrification caused by too short anoxic section in the same reactor in CAST process can be remedied; by adding corn cob solid carbon source, the carbon source in the treatment of low $\mathrm{C} / \mathrm{N}$ wastewater system can be increased. This experiment can overcome the limitation of denitrification process caused by excessive aeration and insufficient carbon source.

(1) The COD of the effluent of the reactor with corn cob solid carbon source and nitrifying bacteria, anoxic denitrifying bacteria and aerobic denitrifying bacteria was maintained at about $30 \mathrm{mg} / \mathrm{L}$, the average effluent concentration of $\mathrm{NH}_{4}{ }^{+}-\mathrm{N}$ decreased from $11.35 \mathrm{mg} / \mathrm{L}$ to $4.58 \mathrm{mg} / \mathrm{L}$ in the control group, and the average effluent $\mathrm{TN}$ concentration decreased from $25.03 \mathrm{mg} / \mathrm{L}$ to $12.11 \mathrm{mg} / \mathrm{L}$ in the control group. The average removal rate of $\mathrm{NH}_{4}{ }^{+} \mathrm{N}$ in the bio-enhanced reactor increased from $55.8 \%$ to $82.1 \%$ in the control group, and the average removal rate of TN increased from $23.2 \%$ to $62.3 \%$ in the control group. The addition of biological agents improves the abundance of denitrifying microorganisms in sludge, increases the types of denitrifying microorganisms, and then improves the denitrification performance of the system, so that the effluent reaches the first A standard. When corn cob is used as carbon source of external reinforcement in activated sludge system, the COD of effluent is stable and low, which will not cause secondary pollution to raw water.

(2) The sludge of the experimental group strengthened by bio-agent and solid carbon source of corncob did not change significantly after 20 days of operation of the reactor. The structure of the sludge was compact and filamentous bacteria and bacilli could be observed obviously. Under the condition of insufficient carbon source in the water environment, the sludge structure of the control group becomes loose and has a certain solution.

(3) Among the six kinds of nitrifying bacteria added, there are three kinds which can exist stably in the system, two of the three kinds of anoxic denitrifying bacteria added can exist stably in the system length, and three kinds of the three kinds of aerobic denitrifying bacteria added can exist stably in the system length. The results showed that the addition of biofortifier could effectively increase the species and abundance of denitrifying microorganisms, change the structure of denitrifying bacteria in sludge system, and improve the denitrification performance of the system.

When corn cob is added to the activated sludge system as a solid carbon source, the amount of corn cob can not be controlled accurately, which may cause secondary pollution. It is suggested that in the future practical application, when external carbon sources need to be added urgently, the leaching solution soaked in corn cob for 2 days should be used instead of the liquid carbon sources commonly used at present; when carbon sources need to be provided slowly for a long time, the corn cob after 2 days should be added to avoid the secondary pollution of water caused by the large amount of COD leached in the initial stage.

Acknowledgements. This work was supported by Liaoning Provincial Natural Science Foundation of China (201602377). 


\section{REFERENCES}

[1] Adouani, N., Limousy, L., Lendormi, T., Sire, O. (2015): N2O and NO emissions during wastewater denitrification step: Influence of temperature on the biological process. Comptes Rendus Chimie 18(1): 15-22.

[2] Bellucci, M., Ofiţeru, I. D., Head, I. M., Curtis, T. P., Graham, D. W. (2013): Nitrification in hybrid bioreactors treating simulated domestic wastewater. - Journal of Applied Microbiology 115(2): 621-630.

[3] Chen, J., Gu, S., Hao, H., Chen, J. (2016): Characteristics and metabolic pathway ofAlcaligenessp. TB for simultaneous heterotrophic nitrification-aerobic denitrification. Applied Microbiology and Biotechnology 100(22): 9787-9794.

[4] Duan, X., Zhou, J., Qiao, S., Yin, X., Tian, T., Xu, F. (2012): Start-up of the anammox process from the conventional activated sludge in a hybrid bioreactor. - Journal of Environmental Sciences 24(6): 1083-1090.

[5] Dvorák, L., Svojitka, J., Wanner, J., Wintgens, T. (2013): Nitrification performance in a membrane bioreactor treating industrial wastewater. - Water Research 47(13): 4412-4421.

[6] Fang, H., Wang, Z., Li, J., Wang, Y. (2015): Denitriding characteristics of a heterotrophic nitrification-aerobic denitrification strain Alcaligenes faecalis No. 4. - Chinese Journal of Environmental Engineering 9(2): 983-988.

[7] Huang, X., Li, W., Zhang, D., Qin, W. (2013): Ammonium removal by a novel oligotrophic Acinetobacter sp. Y16 capable of heterotrophic nitrification-aerobic denitrification at low temperature. - Bioresource Technology 146: 44-50.

[8] Islas-García, A., Vega-Loyo, L., Aguilar-López, R., Xoconostle-Cázares, B., Rodríguez-Vázquez, R. (2015): Evaluation of hydrocarbons and organochlorine pesticides and their tolerant microorganisms from an agricultural soil to define its bioremediation feasibility. - Journal of Environmental Science and Health, Part B 50(2): 99-108.

[9] Jianhua, L., Wenjing, L., Takahashi, J. (2016): High strength ammonium removal in sludge digestate by Alcaligenes faecalis strain No. 4 with heterotrophic nitrification and aerobic denitrification. - Chinese Journal of Environmental Engineering 10(4): 1621-1626.

[10] Joo, H. S., Hirai, M., Shoda, M. (2005): Nitrification and Denitrification in High-Strength Ammonium byAlcaligenes faecalis. - Biotechnology Letters 27(11): 773-778.

[11] Krustok, I., Odlare, M., Truu, J., Nehrenheim, E. (2015): Inhibition of nitrification in municipal wastewater-treating photobioreactors: Effect on algal growth and nutrient uptake. - Bioresource Technology 202: 238-243.

[12] Liu, Y., Wang, Y., Li, Y., An, H., Lv, Y. (2015): Nitrogen removal characteristics of heterotrophic nitrification-aerobic denitrification by Alcaligenes faecalis C16. - Chinese Journal of Chemical Engineering 23(5): 827-834.

[13] Lu, J., Jin, Q., He, Y., He, X., Zhao, J. (2014): Simultaneous Removal of Phenol and Ammonium Using Serratia sp. LJ-1 Capable of Heterotrophic Nitrification-Aerobic Denitrification. - Water, Air \& Soil Pollution 225: 2125.

[14] Magrí, A., Vanotti, M. B., Szogi, A. A. (2012): Anammox sludge immobilized in polyvinyl alcohol (PVA) cryogel carriers. - Bioresource Technology 114: 231-240.

[15] Pan, Y. T., Ni, B.-J., Lu, H. J., Chandran, K., Richardson, D., Yuan, Z. G. (2015): Evaluating two concepts for the modelling of intermediates accumulation during biological denitrification in wastewater treatment. - Water Research 71: 21-31.

[16] Quan, L. M., Khanh, D. P., Hira, D., Fujii, T., Furukawa, K. (2011): Reject water treatment by improvement of whole cell anammox entrapment using polyvinyl alcohol/alginate gel. - Biodegradation 22(6): 1155-1167.

[17] Shoda, M., Ishikawa, Y. (2014): Heterotrophic nitrification and aerobic denitrification of high-strength ammonium in anaerobically digested sludge by Alcaligenes faecalis strain No. 4. - Journal of Bioscience and Bioengineering 117(6): 737-741. 
[18] Skouteris, G., Hermosilla, D., López, P., Negro, C., Blanco, Á. (2012): Anaerobic membrane bioreactors for wastewater treatment: A review. - Chemical Engineering Journal 198-199: 138-148.

[19] Szogi, A. A., Vanotti, M. B., Ro, K. S. (2015): Methods for Treatment of Animal Manures to Reduce Nutrient Pollution Prior to Soil Application. - Current Pollution Reports 1(1): 47-56.

[20] Urakawa, H., Kurata, S., Fujiwara, T., Kuroiwa, D., Maki, H., Kawabata, S., Hiwatari, T., Ando, H., Kawai, T., Watanabe, M., Kohata, K. (2006): Characterization and quantification of ammonia-oxidizing bacteria in eutrophic coastal marine sediments using polyphasic molecular approaches and immunofluorescence staining. - Environmental microbiology 8(5): 787-803. 